\title{
Pengaruh Faktor Diri Sendiri, Faktor Keluarga, Faktor Masyarakat Dan Metode Belajar Terhadap Pengembangan Jiwa Kewirausahaan Mahasiswa
}

\author{
HADIYATI, BAMBANG SUROTO, FATKHURAHMAN \\ Universitas Lancang Kuning \\ Jln. Yos Sudarso Km 08 Rumbai Telp. (0761) 52581 Fax. (0761) 52581 \\ E-mail : fatkhurrahman@unilak.ac.id
}

\begin{abstract}
Malay students are an important part of economic and civilization development, lagging Malay students in Indonesia and Asia in general is a big spotlight. Regarding the readiness to face the world of work and the availability of employment opportunities for existing Malay students is still relatively low. This study uses a survey method with a population of Malay students in Riau Province with sampling in this study using proportional random sampling method and data collected by questionnaire and analyzed by quantitative analysis with multiple linear regression analysis. The results showed that the determinant factors that affect the entrepreneurial spirit of Malay students in Riau from four variables, namely self-factor, family factor, community environmental factor and proven learning method factor that self-factor $(8,362>2,000)$ and family factors $(2,695>2,000)$ significant influence. Whereas community environmental factors $(0.089<2,000)$ and learning methods $(-0.122>-2,000)$ did not have a significant effect
\end{abstract}

Keywords: entrepreneurial spirit, self, family, learning methods and community environment

Kewirausahaan menjadi dasar dan basis program unggulan pada program studi manajemen, sebagai wujud nyatanya maka perlu adanya sebuah kajian yang dapat digunakan untuk dipertimbangkan dalam pengembangan kurikulum mengenai kewirausahaan pada Program Studi Manajemen Fakultas Ekonomi Universitas Lancang Kuning. Penelitian sebelumnya membahas mengenai identifikasi jiwa kewirausahaan pada mahasiswa dan pada penelitian kali ini akan mereduksi mengenai faktor determinan yang mempengaruhi jiwa kewirausahaan tersebut sehingga dapat diperoleh informasi aktual dalam pengambilan keputusan bagi Program Studi Manajemen.

Program studi manajemen bertekad menghasilkan lulusan yang berjiwa enterprenuer (kewirausahaan), jiwa ini perlu diidentifikasi dan perlu dicari faktor determinannya, pada penelitian sebelumnya dan penelitian ini merupakan lanjutan dari penelitian sebelumnya, diketahui bahwa ada teridentifikasikan ada 8 (delapan) jiwa kewirausahaan mahasiswa yakni: pertama kemaun kuat dimiliki mahasiswa menghasikan karya; kedua berkaitan dengan kemampuan membuat keputusan serta berani mengambil resiko dari keputusan yang diambil; ketiga memiliki kreatifitas dengan menghasilkan inovasi dalam produk yang diproduksi; keempat memiliki nilai ketekunan dalam menjalankan aktivitas; kelima yakni memiliki ketelitian dalam memperhitungkan berbagai persoalan; keenam produktif; dan memiliki semangat kebersamaan; serta memegang etika bisnis. Setelah materi kewirausahaan diberikan kepada mahasiswa baik berupa teori maupun praktek diperoleh hasil masih belum optimal walaupun terdapat perbedaan yang signifikan sebelum dan sesudah diberikannya materi.

Faktor determinan memberikan bentuk penyebab dari suatu persoalan, beberapa pendapat ahli sebelumnya seperti yang disampaikan oleh Mopangga (2014: 89) bahwa karakteristik individu, 
lingkungan keluarga dan sosiodemografi serta dukungan akademik menentukan tinggi rendahnya minat wirausaha mahasiswa. Kemudian hasil penelitian Burhanuddin (2013: 1) menjelaskan bahwa faktor determinan jiwa kewirausahaan mahasiswa antara lain: proses belajar mengajar dalam bentuk pratical learning centre dan practical based learning. Juga yang disampaikan oleh Suharti (2011) faktor sosidemografi, faktor sikap, faktor kontektual menjadi faktor determinanya. Menurut hasil sintesa dari Mopangga (2014); Burhanuddin (2013) dan Suharti (2011) bahwa faktor determinan jiwa kewirausahaan mahasiswa antara lain: diri sendiri, keluarga, masyarakat dan metode pembelajaran.

Fenomena mahasiswa di Program Studi Manajemen Fakultas Lancang Kuning dapat dilihat kondisi individu mahasiswa yang penuh dengan antusias mengikuti mata kuliah kewirausahaan dan juga sebagian besar (55\%) mahasiswa termotivasi memilih jurusan manajemen karena ingin memasuki dunia kerja atau sector swasta dan serta masalah latar belakang keluarga mereka hampir 60\% berasal dari keluarga petani dan pedagang serta kondisi metode pembelajaran yang diberikan oleh dosen pengampu mata kuliah kewirausahaan menerapkan 30\% teori dan $70 \%$ praktek kewirausahaan.

Membahas masalah jiwa kewirausahaan dan juga masalah faktor determinan yang mempengaruhi jiwa kewirausahaan menjadi bahasan mendasar. Sebelumnya perlu dijelaskan bahwa wirausaha atau kewirausahaan menurut Sulaiman (2013) adalah berjuang untuk menumbuhkembangkan usaha. Sedangkan menurut Saiman (2009) adalah usahanya untuk menciptakan hal baru yang kreatif serta berani mencobanya serta memiki keberanian dalam mengambil resiko yang mungkin dihadapi.

Kasmir (2007) mejelaskan kewirausahaan merupakan bentuk usaha nyata yang berani mengambil resiko dan mampu membuka peluang dalam mencapai keberhasilan dan mendapatkan kepastian dalam kondisi yang tidak pasti.

Kondisi lainnya sebagaimana dijelaskan oleh (Alma, 2007) bahwa wirausaha yang berani mengambil resiko menjadi sebuah karakteristik utama dalam membangun bisnis. Pentingnya kewirausahaan sebagaimana disampaikan oleh Suryana (2006) yakni sebagai penemu, kemudian sebagai pencetus ide dan juga perencana dalam mencapai sebuah tujuan. Kemudian dijelaskan oleh Syahza \& Indrawati (2007) dengan adanya wirausaha dapat membantu peerintah dalam mengurangi penganguran dan meningkatkan pendapatan masyarakat yang pada gilirannya akan membantu ikut serta dalam meningkatkan pertumbuhan perekonomian bangsa.

Selanjutnya Frinces

(2011)

menjelaskan ada beberaoa peran penting wirausaha yakni dalam memberikan kesempatan kerja da juga menggerakkan kegiatan sektor riil serta kontribusi kepada pajak negara selanjutnya juga sebagai menciptakan keunggulan dalam bersaing dan menciptakan bangsa yang mandiri

Jiwa menurut penulis samaartikan dengan sifat, bahwa penelitian ini menggunakan indikator jiwa kewirausahaan merupakan hasil para ahli yakni Saiman, Frinces dan Saiman (2009) bahwa terdapat delapan indikator jiwa kewirausahaan anara lain: pertama memiliki kemauan berusaha; kedua berani mengambil resiko; ketiga kreatifitas, keempat adanya ketekunan dan kelima memiliki semangat networking kebersamaan; keenam mmemiliki etika dalam berusaha. Sedangkan Z. Heflin Frinces (2011), menjelaskan ada delapan yang berbeda adalah pada hal optimasi dalam produksi. Jadi dapat disintesakan bahwa jiwa kewirausahaan yang digunakan antara lain: mau berkarya, berani, kreatif, networking atau kebersamaan, dinamis menghadapi perubahan dan memiliki kalkulasi beruntung.

p.ISSN: $2407-800 X \quad$ e.ISSN: $2541-4356$ 
Kemudian faktor determinan yang menjadi faktor yang mempengaruhi jiwa kewirausahaan mahasiswa antara lain dijelaskan oleh Dewanti (2008) antara lain karena adanya faktor individual dan juga kondisi lingkungan serta sosiologi kemasyarakatan. Kemudian Alma (2009) menjelaskan antara faktor personal dan lingkungan bersinerji membangun jiwa wirausaha.

Hasil penelitian Mopangga (2014); Burhanuddin (2013) dan Suharti (2011) diduga faktor determinan jiwa kewirausahaan mahasiswa antara lain: diri sendiri, keluarga, masyarakat dan metode pembelajaran.

\section{Diri Sendiri}

Yakni bentuk faktor yang ada dalam diri seorang wirausawan dalam hal ini adalah faktor mahasiswa, dijelaskan bahwa melalui kondisi diri sendiri ini antara lain elemannya: konsep diri yang mengarah kepada apa yang ingin dicapai, kemudian pengetahuan diri dalam berusaha, ketrampilan yang dimiliki, sikap dan perilaku dalam menghadapi dunia nyata dan masalah motivasi diri dalam berprestasi.

2. Faktor Keluarga

Keluarga menjadi contoh dan tauladan dalam diri mahasiswa, dijelaskan bahwa kebiasaan yang dibangun di rumah akan membawa seseorang kearah masa depan. Elemen keluarga itu sendiri antara lain: kebiasaan dalam keluarga dalam berwirausaha, harapan orang tua, dorongan yang diberikan orang tua, contoh nyata sehari-hari.

\section{Faktor Masyarakat}

Masyarakat merupakan faktor lingkungan dimana seseorang melihat kondisi nyata dan menjadi contoh bagi seseorang dan juga menjadi dorongan dalam membangun jiwa kewirausahaan. Elemennya: kondisi lingkungan tempat tinggal yang dinamis, teman sepermainan, kebiasaan masyarakat dan persepsi masyarakat terhadap wirausaha.

4. Faktor Metode Pembelajaran
Metode pembelajaran yang dilakukan di kelas bersama dengan dosen yang memberikan pengajaran dapat dijelaskan bahwa mengenai pemberian teori dan praktek kepada mahasiswa. Elemennya antara lain: sinerji praktikum dengan metode berpusat kepada mahasiswa, penjelasan aturan perkuliahan, materi perkuliahan dan kecakapan dosen.

\section{METODE}

Penelitian ini menggunakan metode kuantitatif, kemudian data primer dan skuncer digunakan adlam penelitian ini. Populasi adalah mahasiswa semester akhir maksudnya adalah Penelitian ini menggunaan objek penelitian yakni mahasiswa senior yang belajar di kampus melayu yakni Universitas Lancang Kuning pada Fakultas Ekonomi sebanyak 79 sampel diambil secara simple random sampling jumlahnya memakai formula slovin. Kuesioner digunakan dan juga observasi. Untuk mengukur pengaruh faktor diri sendiri, keluarga, masyarakat dan metode pembelajaran terhadap jiwa kewirausahaan menggunakan analisis regresi berganda.

\section{HASIL}

Pengujian hipotesis dilakukan dengan dimulai dari koefisien determinasi menunjukkan bahwa faktor determinan (diri sendiri, keluarga, masyarakat dan metode pembelajaran) secara simultan mempengaruhi jiwa kewirausahaan mahasiswa senior menunjukkan bahwa $60,7 \%$ variabel jiwa kewirausahaan mahasiswa dapat dijelaskan oleh variabel diri sendiri, keluarga, masyarakat dan metode pembelajaran, dan 39,3\% dipengaruhi oleh variable lain yang tidak diteliti dalam penelitian ini.

Berikut tabel koefisien determinasi: 
Tabel 1 : Nilai Determinasi

\begin{tabular}{|c|c|c|c|c|}
\hline odel & & Square & \begin{tabular}{|lr} 
& Adj \\
usted & R \\
Square &
\end{tabular} & $\begin{array}{l}\text { Std. } \\
\text { Error of the } \\
\text { Estimate }\end{array}$ \\
\hline & $.779^{a}$ & .607 & .586 & 2.55952 \\
\hline
\end{tabular}

a. Predictors: (Constant), Faktor Metode Belajar, Faktor Keluarga, Faktor Diri Sendiri, Faktor Lingkungan Masyarakat

b. Dependent Variable: Jiwa Kewirausahaan Mahasiswa

Hasil uji ANOVA atau $F$ test dari tabel berikut diperoleh $\mathrm{F}$ hitung lebih besar dibanding dengan $\mathrm{F}$ tabel $(\mathrm{k}-1 ; \mathrm{n}-\mathrm{k}$ atau $5 ; 74)=2,37$. Yaitu 28,574 $>2,37$ dengan tingkat signifikansi 0,000 . Uni Anova ini menyatakan bahwa secara simultan faktor determinan (diri sendiri, keluarga, masyarakat dan metode pembelajaran) mempengaruhi jiwa kewirausahaan mahasiswa.

Selanjutnya hasil uji Anova:

Tabel 2 : Uji ANOVA

\begin{tabular}{|l|l|l|l|l|l|}
\hline Model & $\begin{array}{l}\text { Sum of } \\
\text { Squares }\end{array}$ & f & $\begin{array}{l}\text { Mean } \\
\text { Square }\end{array}$ & & ig. \\
\hline Regression & 748.761 & & 187.190 & 28.574 & $.000^{a}$ \\
Residual & 484.784 & 74 & 6.551 & & \\
Total & 1233.544 & 78 & & & \\
\hline
\end{tabular}

a. Predictors: (Constant), Faktor Metode Belajar, Faktor Keluarga, Faktor Diri Sendiri, Faktor Lingkungan Masyarakat

b. Dependent Variable: Jiwa

Kewirausahaan Mahasiswa

variabel:

Berikut pengaruh dari setiap

Tabel 3: Coeficient

Coefficients $^{\mathrm{a}}$

\begin{tabular}{|c|c|c|c|c|c|}
\hline \multirow[b]{2}{*}{ Model } & \multicolumn{2}{|c|}{$\begin{array}{l}\text { Unstandardized } \\
\text { Coefficients }\end{array}$} & \multirow{2}{*}{$\begin{array}{l}\text { Standardized Coefficients } \\
\text { Beta }\end{array}$} & \multirow[b]{2}{*}{$\mathrm{t}$} & \multirow[b]{2}{*}{ Sig. } \\
\hline & B & $\begin{array}{l}\text { Std. } \\
\text { Error }\end{array}$ & & & \\
\hline 1 (Constant) & 5.520 & 2.778 & & 1.987 & .051 \\
\hline $\begin{array}{l}\text { Faktor Diri } \\
\text { Sendiri }\end{array}$ & 1.064 & .127 & .694 & 8.362 & .000 \\
\hline $\begin{array}{l}\text { Faktor } \\
\text { Keluarga }\end{array}$ & .305 & .113 & .234 & 2.695 & .009 \\
\hline $\begin{array}{l}\text { Faktor } \\
\text { Lingkungan } \\
\text { Masyarakat }\end{array}$ & .013 & .148 & .008 & .089 & .929 \\
\hline $\begin{array}{l}\text { Faktor } \\
\text { Metode } \\
\text { Belajar }\end{array}$ & -.017 & .139 & -.010 & -.122 & .903 \\
\hline
\end{tabular}

Jurnal Daya Saing (Vol. 4, No. 3 Oktober 2018)
Berikut adalah uraian dari hasil penelitian secara parsial:

1. Variabel diri sendiri $(8,362>2,000$ $=$ Ho ditolak) bahwa faktor diri sendiri berpengaruh signifikan terhadap jiwa kewirausahaan mahasiswa

2. Variabel keluarga $(2,695>2,000=$ Ho ditolak) bahwa faktor keluarga berpengaruh signifikan terhadap jiwa kewirausahaan mahasiswa

3. Variabel lingkungan keluarga $(0,089<2,000=$ Ho diterima $)$ ini berarti bahwa faktor lingkungan masyarakat tidak berpengaruh signifikan terhadap jiwa kewirausahaan mahasiswa

4. Variabel metode pembelajaran $(-0,122>-2,000=$ Ho diterima $)$ ini berarti bahwa faktor metode pembelajaran tidak berpengaruh signifikan terhadap jiwa kewirausahaan mahasiswa

Hasil pengujian coeficient seperti disajikan pada tabel tersebut bahwa nilai persamaan regresi berganda yang dihasilkan sebagai berikut:

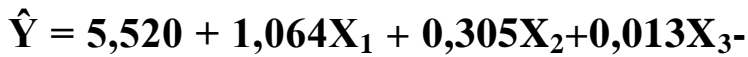 $0,017 \mathrm{X}_{4}$}

Dimana:

$$
\hat{\mathrm{Y}}=\text { Jiwa }
$$

kewirausahaan

$\mathrm{X}_{1} \quad$ = faktor diri sendiri

$\mathrm{X}_{2} \quad$ = faktor keluarga

$\mathrm{X}_{3} \quad$ = faktor lingkungan masyarakat

pembelajaran

$$
\mathrm{X}_{4}=\text { faktor metode }
$$
adalah:

Pengertian dari persamaan tersebut

a. Nilai Constant 5,520 berarti jika tidak ada variabel diri sendiri, keluarga, masyarakat dan metode pembelajaran maka nilai jiwa kewirausahaan adalah sebesar 5,520 satuan.

b. Nilai $X_{1}$ sebesar 1,064 berarti setiap penambahan satu satuan variabel faktor diri sendiri maka

p.ISSN: $2407-800 X \quad$ e.ISSN: $2541-4356$ 
akan meningkatkan jiwa kewirausahaan mahasiswa sebesar 1,064 satuan.

c. Nilai $\mathrm{X}_{2} \quad 0,305$ berarti setiap penambahan satu satuan variabel faktor keluarga maka akan meningkatkan jiwa kewirausahaan mahasiswa sebesar 0,305 satuan.

d. Nilai $X_{3}-0,017$ berarti setiap penambahan satu satuan variabel faktor metode pembalajran maka akan menurunkan jiwa kewirausahaan mahasiswa sebesar 0,017 satuan.

e. Nilai $\mathrm{X}_{3} \quad 0,238$ berarti setiap penambahan satu satuan variabel faktor diri sendiri maka akan meningkatkan jiwa kewirausahaan mahasiswa sebesar 1,064 satuan.

\section{PEMBAHASAN}

Berdasarkan hasil penelitian sebagaimana dijelaskan pada uraian tersebut, maka dapat dibahas beberapa hal:

\section{Pengaruh faktor diri sendiri terhadap jiwa kewirausahaan mahasiswa}

Faktor diri sendiri merupakan bentuk faktor yang ada dalam diri seorang wirausawan dalam hal ini adalah faktor mahasiswa, dijelaskan bahwa melalui kondisi diri sendiri ini antara lain elemannya: konsep diri yang mengarah kepada apa yang ingin dicapai, kemudian pengetahuan diri dalam berusaha, ketrampilan yang dimiliki, sikap dan perilaku dalam menghadapi dunia nyata dan masalah motivasi diri dalam berprestasi.

Variabel diri sendiri $(8,362>2,000=$ Ho ditolak) ini berarti bahwa faktor diri sendiri berpengaruh signifikan terhadap jiwa kewirausahaan mahasiswa

\section{Pengaruh faktor keluarga terhadap jiwa kewirausahaan mahasiswa}

Keluarga menjadi contoh dan tauladan dalam diri mahasiswa, dijelaskan bahwa kebiasaan yang dibangun di rumah akan membawa seseorang kearah masa depan. Elemen keluarga itu sendiri antara lain: kebiasaan dalam keluarga dalam berwirausaha, harapan orang tua, dorongan yang diberikan orang tua, contoh nyata sehari-hari.

Variabel keluarga $(2,695>2,000=$ Ho ditolak) ini bahwa keluarga berpengaruh terhadap jiwa kewirausahaan mahasiswa

\section{Pengaruh faktor lingkungan masyarakat terhadap jiwa kewirausahaan mahasiswa}

Masyarakat merupakan faktor lingkungan dimana seseorang melihat kondisi nyata dan menjadi contoh bagi seseorang dan juga menjadi dorongan dalam membangun jiwa kewirausahaan. Elemennya: kondisi lingkungan tempat tinggal yang dinamis, teman sepermainan, kebiasaan masyarakat dan persepsi masyarakat terhadap wirausaha.

Variabel lingkungan keluarga $(0,089<2,000=$ Ho diterima $)$ ini berarti bahwa faktor lingkungan masyarakat tidak berpengaruh signifikan terhadap jiwa kewirausahaan mahasiswa.

Berbeda dengan hasil penelitian sebelumnya bahwa lingkungan masyarakat memberikan pengaruh yang signifikan, namun pada kasus mahasiswa ini diketahui dengan lingkungan masyarakat mereka saat ini yakni berada di lingkungan rumah kos, kemudian mereka menjalin hubungan dengan masyarakat hanya di social media, sehingga mereka kurang mendapatkan motivasi dalam berusaha.

\section{Pengaruh faktor metode pembelajaran terhadap jiwa kewirausahaan mahasiswa}

Metode pembelajaran yang dilakukan di kelas bersama dengan dosen yang memberikan pengajaran dapat dijelaskan bahwa mengenai pemberian teori dan praktek kepada mahasiswa. Elemennya antara lain: sinerji praktikum dengan metode berpusat kepada p.ISSN: 2407-800X e.ISSN: 2541-4356 
mahasiswa, penjelasan aturan perkuliahan, materi perkuliahan dan kecakapan dosen.

Variabel keluarga $(-0,122>-2,000=$ Ho diterima) ini berarti bahwa faktor metode pembelajaran tidak berpengaruh signifikan terhadap jiwa kewirausahaan mahasiswa. Hal ini juga sejalan dengan apa yang dikatakan oleh Suroto, B., dkk (2017). Metode Penelitian Tindakan Solusi Bagi Masalah Sosial. Jurnal Diklat Review, 1(1), 25-28. bahwa dengan adanya metode belajar yang tepat akan menghasilkan lulusan berkualitas.

\section{SIMPULAN}

Berdasarkan dari hasil penelitian tersebut pada uraian di atas, maka dapat ditarik beberapa kesimpulan penelitian sebagai berikut:

a. Secara parsial faktor diri sendiri, keluarga yang berpengaruh signifikan tehadap jiwa kewiausahaan mahasiwa sedangkan faktor lingkungan masyarakat dan metode pembelajaran secara parsial tidak mempengaruhi jiwa kewirausahaan mahasiswa semester akhir program studi manajemen semester VII Fakultas Ekonomi Universitas Lancang Kuning

b. Secara simultan faktor determinan (diri sendiri, keluarga, masyarakat dan metode pembelajaran) berpengaruh signifikan terhadap jiwa kewirausahaan mahasiswa semester akhir program studi manajemen semester VII Fakultas Ekonomi Universitas Lancang Kuning

\section{DAFTAR RUJUKAN}

Alma, Buchari, 2007, Kewirausahaan, edisi revisi, Alfabeta, Bandung.

Burhanuddin, 2013, Faktor Determinan Proses Belajar Mengajar Kewirausahaan di Institut Pertanian Bogor, Konferensi Nasional
"Inovasi dan Technopreneurship" IPB, Bogor 18-19 Februari 2013.

Dewanti, 2008, Kewirausahaan, Mitra Wacana Media. Jakarta.

Kasmir, 2007, Kewirausahaan, PT RajaGrafindo Perkasa, Jakarta.

Mopangga, Herwin, 2014, Faktor Determinan Minat Wirausaha Mahasiswa Fakultas Ekonomi dan Bisnis Universitas Negeri Gorontalo, Jurnal Trikonomika, Volume 13 Nomor 1 Hal 78-79.

Saiman, Leonardus, 2009, Kewirausahaan, Teori, Praktik dan Kasus-kasus, Salemba Empat, Jakarta.

Sulaiman, Suhendar, 2013, Cara Mudah Menjadi Wirausahawan Sukses, Bahan Ajar Mata Kuliah Kewirausahaan, Universitas Muhammadiyah Jakarta.

Suryana, 2006, Kewirausahaan : Pedoman Praktis Kiat dan Sukses Menuju Sukses. Salemba Empat. Jakarta.

Suharti, Lieli dan Sirine, Hani, Faktorfaktor yang berpengaruh terhadap Niat Kewirausahaan (Enreprenuerial Intenstion) (Studi terhadap mahasiswa Universitas Kristen Satya Wacana, Salatiga). Jurnal Manajemen dan Kewirausahaan, Volume 13 No 3, September 2013 Hal 124-134

Suroto, B., Novita, N., Pailis, E. A., Waldelmi, I., \& Fatkhurahman, F. (2017). Metode Penelitian Tindakan Solusi Bagi Masalah Sosial. Jurnal Diklat Review, 1(1), 25-28. 
Pengaruh Faktor Diri Sendiri, Faktor Keluarga, Faktor Masyarakat Dan Metode Belajar Terhadap

Pengembangan Jiwa Kewirausahaan Mahasiswa (Hadiyati, Bambang Suroto, Fatkhurahman)

Syahza \& Indrawati, 2007, Privatization and Entrepreneurial Transformation

: Emerging Issues and a Future

Reseach Agenda, Academy of Management Review, 25: 509 - 524.

Z.Heflin Frinces, 2011, $B e \quad A n$

Entrepreneur. Graha Ilmu.

Yogyakarta. 